\title{
Konstruksi Konten Vlog Penerima Diamond Play Button Di Youtube Indonesia
}

\author{
Nunik Hariyani \\ Program Studi Ilmu Komunikasi, Universitas Merdeka Madiun, Jl. Serayu No.79, Madiun, 63133 \\ E-mail: hariyani_nunik@yahoo.com
}

\begin{abstract}
The existence of YouTube since 2005, is currently the second most popular social network in the world after Facebook. YouTube users in the world 1.9 billion. YouTube is used to share content and comments. This video-based social media is used to share videos and comment on one another. YouTube users in Indonesia have reached 50 million people. This research will look at how YouTube's Atta Halilintar and Ricis Official content constructions are recipients of the Diamond Play Button award, and how the creative strategy used by YouTuber in its video content. The results of this study are YouTube being the most active social platform used in Indonesia today. Youtube is used for identity and as a promotional media based on PPC (Pay Per Click) where every video that is deemed eligible in it contains Google Adsense ads. Youtube is a money field for many YouTubers in Indonesia with creative concepts according to popular culture.
\end{abstract}

Keywords—: YouTube; Creative Strategy; Video Content; Construction.

\section{LATAR BELAKANG}

Salah satu media hiburan di internet yang paling banyak diakses di Indonesia adalah YouTube. Keleluasaan masyarakat yang dapat berperan sebagai kreator sekaligus penonton menjadi daya tarik masyakarat Indonesia untuk menggunakan YouTube. Tingginya akses masyarakat Indonesia terhadap YouTube pada akhirnya menarik minat perusahaan untuk menjadikan YouTube sebagai media pemasaran baru. Keuntungan yang didapatkan oleh Google, parent-corporate dari YouTube, mencapai 14,3 milyar USD pada kuartal pertama tahun 2016 (Meola, 2016). Keuntungan tersebut didapatkan dari iklan yang ditayangkan pada search engine dan iklan di YouTube. Lingkungan YouTube yang sangat mendukung pertumbuhan kreator dan penonton berkontribusi dalam meningkatkan minat masyarakat untuk menggunakan YouTube. Tingginya frekuensi penggunaan YouTube berdampak pada tingginya minat perusahaan untuk menggunakan YouTube sebagai media pemasaran. Investasi yang ditanamkan perusahaan kepada YouTube akhirnya meningkatkan kesadaran YouTube untuk terus membangun komunitas kreator di dalam platform-nya, salah satunya dengan memberikan keuntungan materiil melalui ad revenue. Keuntungan materiil yang digabungkan dengan fungsi YouTube sebagai media ekspresi diri lah yang menjadi faktor bagi tingginya minat masyarakat untuk menjadi creator YouTube.

Penelitian-penelitian sebelumnya menunjukkan bahwa keterbukaan di era masyarakat jejaring dan platform yang disediakan oleh YouTube tidak hanya memberikan ruang bagi kreator untuk mengekspresikan diri, namun juga memberikan kesempatan bagi penonton untuk memilih jenis tontonan yang ingin mereka tonton. Bertemunya kedua kepentingan tersebut merupakan dasar dari munculnya engagement antara kreator dan penonton. Proses komodifikasi yang terjadi memang tidak dapat dihindari, namun terjadinya komodifikasi pada konteks masyarakat jejaring memberikan beberapa penyesuaian pada konsep komodifikasi itu sendiri. Sumber daya praktis berupa teknologi yang lebih mudah diakses akibat proses kapitalisasi perangkat menjadi awal dari proses komodifikasi yang terjadi di tengah masyarakat jejaring. Tidak hanya itu, konteks masyarakat pada era digital yang pada dasarnya merupakan pekerja intelektual yang memiliki nilai tukar, membuat masyarakat memiliki otonomi pada derajat tertentu dalam sebuah ekonomi informasi dimana suatu ide telah direifikasi, bersifat publik, dan terkomodifikasi (Smith, 2013 Thrift 2005, 2006 dalam Lupton, 2015: 22). Keterbukaan akses masyarakat terhadap komponen praktis dan esensial dari komoditas tersebut pada akhirnya mempengaruhi peran dan posisi aktor yang terlibat. Peran dari masing-masing aktor yang terlibat tidak lagi se-rigid yang diutarakan Adorno melalui konsep komodifikasi. Seperti yang diutarakan sebelumnya engagement muncul akibat bertemunya pilihan selera penonton dengan kepentingan ekspresi diri kreator. Basis engagement inilah yang membuat YouTube sadar untuk mempertahankan engagement tersebut dalam rangka mempertahankan eksistensinya. Engagement tersebut pula yang menjadi dasar dari ketertarikan perusahaan untuk menjadikan YouTube sebagai media pemasaran baru. Berdasarkan fenomena tersebut, penelitian ini bertujuan untuk menonjolkan keunikan konteks masyarakat jejaring dalam memberikan perspektif baru terhadap konsep komodifikasi dengan menjelaskan proses komodifikasi ide yang terjadi di era masyarakat jejaring, dalam kasus YouTube Indonesia, serta tipologi kreator dan relasi antar aktor yang terlibat dalam proses komodifikasi tersebut. YouTube telah menjadi salah satu bentuk budaya digital di dunia. Jumlah pengguna yang lebih dari tujuh puluh juta setiap bulan dan sekitar delapan puluh juta video online, platform terdistribusi berupa video yang memiliki gudang budaya populer terkaya di Internet (Snickars, 2010).

Perkembangan fungsi YouTube yang tidak hanya sebagai wadah ekspresi diri namun juga menjadi media pemasaran korporasi mempertegas bahwa telah terjadi proses komodifikasi pada proses kreatif kreator yang memanfaatkan kreatifitas, 
Website : http://sosial.unmermadiun.ac.id/index.php/sosial

ruang ekspresi diri, dan interaksi antara penonton dan kreator. Sebagai situs dengan pertumbuhan tercepat dalam sejarah Web, YouTube menjanjikan peluang baru yang tak ada habisnya untuk video amatir, kampanye politik, format hiburan, dan pemasaran klip budaya yang tampaknya melampaui bioskop dan televisi.

Keberadaan YouTube sejak tahun 2005, saat ini menjadi jejaring sosial ke dua yang paling popular di dunia setelah facebook. Dengan pengguna 1,9 milyar (Infopedia, 2019). YouTube digunakan untuk saling berbagi konten dan komentar. Media sosial berbasis video ini digunakan untuk berbagi video dan saling memberikan komentar. Pengguna YouTube di Indonesia sudah mencapai 50 juta orang (InpemediaTv, 2019). YouTube menjadi platform sosial yang paling aktif digunakan di Indonesia saat ini. Youtube digunakan sebagai media promosi berbasis PPC (Pay Per Click) dimana setiap video yang dianggap memenuhi syarat di dalamnya terdapat iklan Google Adsense. Youtube menjadi ladang uang bagi banyak YouTuber di Indonesia.

YouTuber Indonesia penerima Diamond Play Button pertama di Asia Tenggara adalah Atta Halilintar dan Ria Ricis pada tanggal 20 februari 2019. Penghargaan ini di dapat karena mendapatkan 10 juta subscriber di chanel youtube mereka. Jumlah subscriber mereka terbanyak di Asia Tenggara. Penghargaan diberikan oleh Rajant Meshran, Yootube Creator and Artis Development Manager untuk Indonesia dan Asia Tenggara.

Penelitian berusaha mengungkap konten Youtube yang terjadi di era masyarakat jejaring dengan berfokus kepada kasus kreator YouTube Indonesia. Penelitian dilakukan menggunakan pendekatan kualitatif untuk menjelaskan kasus komodifikasi ide di YouTube Indonesia menggunakan teknik analisis konten.

\section{A. Rumusan Masalah}

Permasalahan dalam penelitian ini diidentifikasi sebagai berikut:

1. Bagaimana konstrusi konten YouTube Atta Halilintar dan Ricis Official sebagai penerima penghargaan Diamond Play Button?

2. Bagaiamana strategi kreatif yang digunakan YouTuber pada konten videonya?

\section{B. Tujuan Penelitian}

Berdasarkan rumusan masalah di atas, maka tujuan yang hendak dicapai dalam penelitian ini adalah:

1. Mengetahui bagaimana YouTube menjadi salah satu bentuk industri, arsip, dan budaya.

2. Memberikan pandangan yang lebih dekat pada konten yang tersedia di YouTube yang ke depannya dapat dirumuskan kebijakan serta norma untuk mengatur akses dan penggunaannya.

3. Mengetahui perkembangan fungsi YouTube, tidak hanya sebagai wadah ekspresi diri namun juga menjadi media pemasaran korporasi guna mempertegas bahwa telah terjadi proses komodifikasi pada proses kreatif kreator yang memanfaatkan kreatifitas, ruang ekspresi diri, dan interaksi antara penonton dan kreator.

\section{Manfaat Penelitian}

Penelitian ini diharapkan mampu memberikan manfaat secara:

1. Akademis

Dapat menambah khasanah ilmu komunikasi tentang keterbukaan di era masyarakat jejaring memberikan ruang yang lebih leluasa bagi masyarakat untuk ikut memonopoli sumber daya (dalam konteks hiburan online). Sehingga, tidak hanya berpotensi untuk menghindarkan kreator dari alienasi sebagai dampak negatif dari proses komodifikasi, keterbukaan di era masyarakat jejaring juga menegaskan semakin cairnya posisi dan bentuk eksploitasi pada setiap aktor yang terlibat.

2. Memberikan manfaat bagi masyarakat dan peneliti sendiri guna memahami posisi media sosial di tengah masyarakat saat ini sebagai salah satu media online. Dan dapat menjadi riset yang berkelanjutan untuk dikembangkan ke riset-riset yang lebih mendalam dan komprehensif.

\section{TINJAUAN PUSTAKA}

\section{A. Analisis Pesan}

Analisa pesan adalah suatu metoda untuk menyelidiki dan meneliti tentang bagaimana komunikator merancang-bangun pesan agar memperoleh hasil tindak komunikasi yang efikas (optimal dan efisien). Pesan pada dasarnya adalah produk dari komunikator yang disampaikan kepada komunikan (publik) baik secara langsung maupun melalui media. Pesan biasanya diikuti oleh motif komunikator. Berarti setiap pesan yang bersifat intensional mempunyai tujuan. Tujuan tersebut digunakan mencapai kekuasan, baik kekuasaan secara sosial, politik, ekonomi dan budaya.

Pesan dalam bahasa Prancis ditulis message (baca: mesaz), berasal dari bahasa latin "missus" artinya mengirim. Kata message digunakan sejak akhir abad ke XI oleh para penutur atau partisipan komunikasi untuk mengatakan "sesuatu yang kita kirimkan" (ce que l'on transmet, baca: Dictionaire de Petit Robert). Pesan terdiri atas sekumpulan tanda-tanda yang dikelola berdasarkan kode-kode tertentu yang dipertukarkan antara komunikator dan komunikan melalui saluran (ensemble de signaux organises selon un code et qu'un emetteur transmet a un recepteur par l'intermediare d'un canal). Untuk konteks di negara Prancis, pengertian "message" selalu dihubungkan dengan semiology (ilmu tentang tanda) dan cybernetique (ilmu tentang dunia maya). Pesan juga dapat berarti komunikasi politik antar lembaga negara, suatu penggambaran komunikasi resmi yang dilakukan oleh kekuasaan eksekutif (pejabat negara) dan kekuasaan legislatif. Dari uraian di atas dapat disimpulkan bahwa 
Website : http://sosial.unmermadiun.ac.id/index.php/sosial

pesan adalah representasi gagasan komunikator yang dipertukarkan dalam wujud tanda-tanda tertentu (utamanya yang bersifat fisik), yang isinya mengandung maksud tertentu. Pesan biasanya dengan sengaja disalurkan oleh komunikator kepada komunikan untuk mendapatkan hasil tertentu, yang biasanya telah ditetapkan.

Jadi, penggunaan kata pesan sebagai unsur komunikasi, berisi (content) tentang informasi yang dikirimkan oleh sumber kepada penerima, seperti percakapan langsung (interpersonal communication) maupun lewat media massa (mass communication), seperti telpun, media cetak, handphone, internet dan elektronik lainnya, dalam bentuk kemasan pesan (message packaging). Bentuk kemasan pesan seperti iklan, film, buku, brosur, baliho, website, televisi, radio, seluruhnya menunjukkan isi pesan atau sering disebut sebagai media content. Dalam hal terakhir ini, McLuhan mengatakan medium is message (McLuhan, 1964).

Dari uraian di atas, definisi pesan, penulis artikan sebagai: "rancang bangun gagasan" (message engineering) yang dikemas (message packaging) sedemikian rupa, memuat di dalamnya terdapat motif pesan (message meaning), dikirim dan dipertukarkan kepada target tertentu (message using), dalam sebuah tindak komunikasi (communication action) pada ruang dan waktu tertentu.

\section{B. Media Sosial}

Menurut Carr dan Hayes, definisi atau pengertian yang telah dirumuskan seringkali merujuk media sosial pada tiga hal utama, yaitu Teknologi digital yang menekankan pada user-generated content atau interaksi, karakteristik media, dan Jejaring sosial seperti Facebook, Twitter, Instagram, dan lain-lain sebagai contoh model interaksi. Menurut McGraw Hill Dictionary, Media sosial adalah sarana yang digunakan oleh orang-orang untuk berinteraksi satu sama lain dengan cara menciptakan, berbagi, serta bertukar informasi dan gagasan dalam sebuah jaringan dan komunitas virtual. Menurut Varinder Taprial dan Priya Kanwar (2012), Media sosial adalah media yang digunakan oleh individu agar menjadi sosial, atau menjadi sosial secara daring dengan cara berbagi isi, berita, foto dan lain-lain dengan orang lain. Joyce Kasman Valenza (2014) mendefinisikan Media sosial adalah platform internet yang memungkinkan bagi individu untuk berbagi secara segera dan berkomunikasi secara terus menerus dengan komunitasnya.

Menurut Andreas M. Kaplan dan Michael Haenlein (2010) membagi berbagai jenis media sosial ke dalam 6 (enam) jenis, yaitu:

1. Collaborative projects memungkinkan adanya kerjasama dalam kreasi konten yang dilakukan oleh beberapa pengguna secara simultan, misalnya adalah Wikipedia. Beberapa situs jenis ini mengizinkan penggunanya untuk melakukan penambahan, menghilangkan, atau mengubah konten. Bentuk lain dari collaborative projects adalah social bookmarking yang mengizinkan koleksi berbasis kelompok dan peringkat kaitan internet atau konten media.

2. Blogs merupakan salah satu bentuk media sosial yang paling awal yang tumbuh sebagai web pribadi dan umumnya menampilkan date-stamped entries dalam bentuk kronologis. Jenis blog yang sangat populer adalah blog berbasis teks.

3. Content communities memiliki tujuan utama untuk berbagi konten media diantara para pengguna, termasuk didalamnya adalah teks, foto, video, dan powerpoint presentation. Para pengguna tidak perlu membuat halaman profil pribadi.

4. Social networking sites memungkinkan para pengguna untuk terhubung dengan menciptakan informasi profil pribadi dan mengundang teman serta kolega untuk mengakses profil dan untuk mengirim surat elektronik serta pesan instan. Profil pada umumnya meliputi foto, video, berkas audio, blogs dan lain sebagainya. Contoh dari social networking sites adalah Facebook, MySpace, dan Google+.

5. Virtual games worlds merupakan platform yang mereplikasi lingkungan ke dalam bentuk tiga-dimensi yang membuat para pengguna tampil dalam bentuk avatar pribadi dan berinteraksi berdasarkan aturan-aturan permainan.

6. Virtual sosial worlds memungkinkan para inhabitan untuk memilih perilaku secara bebas dan untuk hidup dalam bentuk avatar dalam sebuah dunia virtual yang sama dengan kehidupan nyata. Contohnya adalah Second Life.

Fungsi media sosial dapat kita ketahui melalui sebuah kerangka kerja honeycomb. Pada tahun 2011, Jan H. Kietzmann, Kritopher Hermkens, Ian P. McCarthy dan Bruno S. Silvestre, menggambarkan hubungan kerangka kerja honeycomb sebagai penyajian sebuah kerangka kerja yang mendefinisikan media sosial dengan menggunakan tujuh kotak bangunan fungsi yaitu identity, cenversations, sharing, presence, relationships, reputation, dan groups.

Identity menggambarkan pengaturan identitas para pengguna dalam sebuah media sosial menyangkut nama, usia, jenis kelamin, profesi, lokasi serta foto. Conversations menggambarkan pengaturan para pengguna berkomunikasi dengan pengguna lainnya dalam media sosial. Sharing menggambarkan pertukaran, pembagian, serta penerimaan konten berupa teks, gambar, atau video yang dilakukan oleh para pengguna. Presence menggambarkan apakah para pengguna dapat mengakses pengguna lainnya. Relationship menggambarkan para pengguna terhubung atau terkait dengan pengguna lainnya. Reputation menggambarkan para pengguna dapat mengidentifikasi orang lain serta dirinya sendiri. Groups menggambarkan para pengguna dapat membentuk komunitas dan sub-komunitas yang memiliki latar belakang, minat, atau demografi.

\section{YouTube}

Youtube adalah media massa baru yang memiliki viewers. YouTube pertama kali didirikan pada tahun 2005 sebagai sebuah projek audiovisual untuk berbagi video amatir antara ketiga pendirinya, Chad Hurley, Steve Chen, dan Jawed Karim. Hingga saat ini, YouTube dapat dikases dalam 76 bahasa oleh penonton berusia 18-34 tahun di 88 negara. Setiap harinya, YouTube dapat menjangkau $95 \%$ populasi internet dunia dan menghasilkan miliaran kali penayangan, setara dengan durasi tonton 
sebanyak ratusan juta jam. Masuknya YouTube ke Indonesia pada tahun 2012 menjadikan Indonesia sebagai negara ke-46 di dunia yang resmi memiliki domain negaranya sendiri (youtube.co.id).

YouTube memiliki sebuah program bernama YouTube Partnership Program. YouTube Partnership Program dirancang khusus untuk individu yang ingin menjadi kreator tetap YouTube. Untuk dapat bergabung ke dalam YouTube Partnership Program, creator harus terlebih dahulu memiliki akun Google untuk membuat saluran dan akun Adsense untuk menerima pembayaran. Setelah itu, kreator harus memiliki jumlah video, jumlah penayangan, dan jumlah penonton dengan peningkatan yang konsisten. Aktivitas kreator harus mematuhi persyaratan layanan, pedoman komunitas, dan pedoman hak cipta agar dapat secara konsisten menjadi saluran yang ramah pengiklan (advertiser friendly). YouTube senantiasa mengedukasi kreator mengenai berbagai macam hal yang berkaitan dengan aktivitas kreatifnya di YouTube. Berbagai jenis dukungan layanan dan fasilitas tersebut diatur berdasarkan jumlah subscribers yang dimiliki oleh kreator. Kreator yang telah menjadi bagian dari YouTube Partnership Program dapat memonetisasi video yang mereka buat. Proses monetisasi ini memungkinkan kreator untuk mendapatkan keuntungan berupa uang dari penayangan iklan pada video dan/atau laman video Para kreator menyatakan bahwa mereka sudah mengetahui YouTube sejak pertama kali diluncurkan pada tahun 2005. Hanya saja, kreator belum menyadari YouTube sebagai video sharing platform, namun hanya melihat YouTube sebagai situs tempat mereka menonton video klip dan mendengarkan lagu. Para kreatorpun sebelumnya hanya penonton dan belum memiliki keinginan untuk menjadi kreator. Berdasarkan keterangan informan, tipe konten yang pada umumnya dibuat adalah vlog (video blogging). Vlog merupakan sebuah video dimana kreator memperlihatkan dan/atau membicarakan topik yang diinginkan seperti, kehidupan pribadi, opini, hobi, dan lain sebagainya.

\section{III.METODE PENELITIAN}

Jenis penelitian ini adalah deskriptif dengan pendekatan kualitatif Menurut Whitney, penelitian deskriptif adalah pencaraian fakta dengan interpretasi yang tepat dengan tujuan untuk membuat deskripsi, gambaran/ lukisan, secara sistematis, faktual dan akurat mengenai fakta-fakta, sifatsifat serta hubungan-hubungan antar fenomena yang diselidiki. Sementara penelitian kualitatif bertitik tolak dari paradigma fenomenologis yang objektivitasnya dibangun atas rumusan tentang situasi tertentu sebagaimana yang dihayati oleh individu atau kelompok sosial tertentu dan relevan dengan tujuan penelitian itu. Tujuan penelitian kualitatif adalah bukan untuk selalu mencari sebab akibat sesuatu, tetapi lebih berupaya memahami situasi tertentu (Moleong, 2002: 15)

Penelitian dilakukan menggunakan pendekatan kualitatif. Jenis penelitian sosial dikategorikan ke dalam empat dimensi, yakni dimensi kegunaan, tujuan, waktu, dan teknik pengumpulan data (Neuman, 2006: 23). Berdasarkan dimensi kegunaan, penelitian ini merupakan basic research yang bertujuan untuk mendukung atau membantah sebuah teori dalam rangka menjelaskan bagaimana sebuah fenomena sosial terjadi. Berdasarkan dimensi tujuan, penelitian ini bersifat deskriptif. Penelitian bertujuan untuk menjelaskan bagaimana fenomena komodifikasi pada proses kreatif kreator YouTube Indonesia terjadi. Berdasarkan dimensi waktu, penelitian ini merupakan sebuah penelitian studi kasus yang ditujukan untuk melihat bagaimana sebuah fenomena sosial dapat terjadi dalam sebuah kasus partikular. Terakhir, berdasarkan teknik pengumpulan data, penelitian ini merupakan penelitian lapangan (field research). Penelitian menempatkan YouTube Indonesia sebagai unit analisis dan kreator YouTube Indonesia sebagai unit observasi. Adapun unit observasi penelitian adalah creator YouTube Indonesia yang membuat video dengan tipe user-generated.

Pembahasan penelitian akan didasari pemahaman tentang komodifikasi oleh Adorno yang muncul pada konteks masyarakat kapitalis pasca era pencerahan (enlightment). Adorno (1991) menyadari adanya usaha untuk menghilangkan individualitas dengan membuat masyarakat patuh terhadap keteraturan dan sistem. Keteraturan dan sistem yang dimaksud adalah pemahaman mengenai kedua konsep berdasarkan pihak dominan pada konteks masyarakat tersebut, yakni kapitalis. Sehingga, dalam konteks industri budaya, Adorno juga menekankan aktor yang terlibat beserta dengan peran yang mereka miliki dalam proses komodifikasi, dimana produsen akan selalu mendominasi konsumen dan akhirnya kedua pihak teralienasi dari produk budaya yang dipertukarkan. Hanya saja, konteks masyarakat yang belum terlalu kompleks menjadikan pembahasan Adorno mengenai komodifikasi produk budaya terbatas pada media (televisi, radio) dan industri hiburan (film, musik) yang berkembang saat itu. Pemikiran mengenai komodifikasi pada konteks masyarakat yang lebih kompleks dibahas oleh Baudrillard.

Baudrillard (1981) menjelaskan bagaimana pesatnya perkembangan teknologi dan arus informasi menjadikan masyarakat sangat bergantung kepada media untuk mendapatkan informasi seputar hal yang terjadi di dunia dan melegitimasi peran media untuk melakukan hal tersebut. Jika sebelumnya Adorno menegaskan adanya usaha kapitalis untuk menyeragamkan ideologi masyarakat melalui produk budaya, maka Baudrillard menegaskan bahwa individualitas masyarakat sebagai sebuah subjek pun telah menjadi sebuah komoditi. Sistem media yang sangat adaptif dalam memanfaatkan posisi masyarakat sebagai subjek maupun objek menyempitkan pilihan masyarakat dalam melakukan resistensi terhadap sistem yang bekerja atas mereka. Tesis Adorno dan Baudrillard mengindikasikan adanya posisi rigid yang dimiliki setiap aktor dalam proses komodifikasi. Akan ada aktor yang mendominasi dan terdominasi di dalam proses komodifikasi yang terjadi. Namun keterbukaan dalam konteks masyarakat jejaring tidak hanya memungkinkan negosiasi nilai, namun juga posisi dari setiap aktor yang terlibat dalam interaksi yang terjadi (Bolaño dan Vieira, 2015; Kangal, 2016; Fuchs, 2016).

Perspektif struktural tentang masyarakat yang terdiri dari sistem hierarki yang kaku (rigid) tidak lagi relevan mengingat bentuk kekuasaan pada konteks masyarakat digital menjadi lebih horizontal, non-hierarkis, cair, dan dinamis (Lupton, 2015: 22) Konteks keterbukaan di era masyarakat jejaring menjadi konsep yang berusaha melihat relevansi konsep Adorno mengenai komodifikasi ide di era masyarakat jejaring. Kelekatan masyarakat jejaring terhadap teknologi serta kapitalisasi dan 
Website : http://sosial.unmermadiun.ac.id/index.php/sosial

keterbukaan akses masyarakat terhadap komponen esensial serta praktis dari sumber daya ekonomi era informasi merupakan sebuah jalan bagi masyarakat dalam merebut kembali posisinya sebagai subjek. Penelitian berusaha memindahkan fokus argumen yang dikotomis mengenai komodifikasi di era masyarakat jejaring dengan mengamati kasus yang sesungguhnya terjadi di masyarakat, dan melihat dampak lanjut dari fenomena tersebut.

\section{A. Objek Penelitian}

Objek penelitian ini adalah konten youtube. Dalam penelitian ini, peneliti melakukan penelitian secara kualitatif.

\section{B. Teknik Pengumpulan Data}

1. Observasi

Karl Werck mendefinisikan observasi sebagai pemilihan, pengubahan, pencatatan, dan pengkodean serangkaian perilaku dan suasana yang berkenaan dengan organisme in situ sesuai dengan tujuan empiris (Rakhmat, 1985: 95). Fokus observasi dalam penelitian ini diarahkan pada pengamatan langsung terhadap pesan politik di group publik facebook.

2. Dokumentasi

Sebagai data sekunder teknik pengumpulan dokumentasi diperoleh dari buku, artikel, jurnal ilmiah, penelitian terdahulu serta data pendukung lain yang berkaitan dengan penelitian reifikasi iklan kampanye pemilu 2014 di media sebagai konstruksi realitas politik.

3. Triangulasi

Pada teknik ini peneliti mengadopsi teknik analisis yang dikemukakan oleh Miles dan Haberman yaitu: reduksi data, penyajian data (display data) dan menarik kesimpulan (Verifying conclusion).

\section{Teknik Analisia Data}

Penelitian ini memfokuskan diri pada pesan yaitu konten youtube. Penelitian ini menggunakan metode analisis pesan dengan tahapan sebagai berikut:

1. Menganalisa makna konten pesan (message meaning),

2. Menganalisa rancang-bangun konten pesan, (message engineering)

3. Menemukan kemasan konten pesan (message packaging),

4. Meneliti cara penggunaan konten pesan (message using).

Keempat tahapan tersebut, seluruhnya berbasis dan bertumpu pada wacana (discourse), agensi (partisipan komunikasi) dan struktur (institusi dan pranata sosial-budaya) sebagai unit analisis.

\section{IV.HASIL DAN PEMBAHASAN}

Berdasarkan hasil observasi pada konten YouTube Atta Halilintar dan Ricis official menunjukkan bahwa pembuatan video blog (vlog) pada channel tersebut menggunakan konsep seadanya. Konsep video yang viral dikemas dengan berbagai macam konten. Pertama, konsep How to tutorial, atau DIY (Do It Your Self). Konsep video Atta Halilintar dan Ricis official berupa tayangan yang memberikan pengetahuan untuk menyelesaikan suatu permasalahan. Misalnya tentang cara membuat sesuatu atau semacam tutorial. Video ini banyak dicari dan dan ditunggu para netizen, karena memudahkan mereka mencari solusi dari permasalahan yang mereka hadapi.

Kedua, konsep wawancara. Video dengan konsep wawancara berusaha dipilih supaya memberi kesan menarik. Narasumber yang diwawancara Atta Halilintar dan Ricis official cukup ternama, kompeten, dan ditunggu komentarnya oleh para netizen. Agar video berkonsep wawancara yang dibuat untuk memikat banyak penonton, berbagai topik dibahas suaya menarik dan mengambil tema sesuai yang sedang 'hangat' dibahas banyak orang.

Ketiga, konsep prank. Konsep video prank atau aksi usil, tema ini dipilih supaya ditonton banyak orang karena sifatnya yang menghibur. Untuk membuat video ini, Atta Halilintar dan Ricis official melakukan aksi usil/jebakan pada teman. aksi mereka terekam kamera dengan tujuan untuk menghibur dan menimbulkan reaksi alami yang tak terduga.

Keempat, konsep challenge. Selain prank, konsep video dipilih Atta Halilintar dan Ricis official yaitu tantangan atau challenge. Tantangan yang dilakukan lebih terkonsep supaya lebih menarik dan membuat penasaran penonton. Jangan khawatir jika tantangan yang Anda lakukan ternyata, gagal. Karena itu juga bisa membuat penonton penasaran untuk mencobanya hingga berhasil. Beberapa video tantangan yang sempat viral adalah mannequin challenge, baby shark challenge dan lain-lain.

Kelima, dokumenter pendek. Konsep pada konten Atta Halilintar dan Ricis official dipilih untuk meningkatkan ketertarikan dengan mengangkat suatu permasalahan di tengah masyarakat. Video dokumenter, yaitu tidak hanya memberikan tontonan tapi juga memberikan informasi yang menarik dan bermanfaat. Video pada konten Atta Halilintar dan Ricis official ditambahkan dengan narasi yang bagus, sehingga membuat penonton ikut dalam cerita video dokumenter tersebut.

Keenam, konsep karaoke/cover song. Video karaoke atau cover song dilakukan Atta Halilintar dan Ricis official karena memiliki ketertarikan pada musik, atau memiliki suara yang bagus. Konsepnya dengan membuat video saat bernyanyi atau memainkan alat musik. Hal paling mudah adalah dengan meng-cover lagu yang sudah terkenal. Selain itu apabila creator belum bisa melakukan cover, dengan melakukan karaoke. Dengan menyanyikan lagu yang sedang hits dengan suara emas yang dimiliki, video menjadi booming dan banyak ditonton. 
Ketujuh, konsep event. Konsep ini terkesan menunjukkan cara paling mudah yaitu dengan merekam suatu event. Kegiatannya Atta Halilintar dan Ricis official antara lain dengan cara merekam kejadian, aktivitas sehari-hari, momen penting seperti hari ulang tahun atau pernikahan, dan lainnya. Creator dengan melakukan datang ke suatu acara yang dianggap penting dan dinanti banyak orang, yaitu konser atau event acara tertentu.

Kedelapan, konsep Q\&A video. Video tanya jawab atau Question \& Answer (Q\&A), menjadi konsep ide lainnya. Pada video ini Atta Halilintar dan Ricis official melibatkan penonton untuk menjawab pertanyaan dari creator atau penonton lainnya. Interaksi penonton melalui komentarnya menjadi hal penting dalam konsep video ini. Rasa penasaran penonton akan terjawab lewat konsep video Q\&A. Konsep video ini juga bisa mendekatkan creator dengan penonton atau subscriber.

Kesembilan, konsep main game. Konsep ini ditujukan Atta Halilintar dan Ricis official kepada para gamer, konsep video sebagai satu pilihan konsep dari buadaya yang ladi digemari yaitu bermain game online. Konsep video ini banyak disukai oleh mereka yang juga ingin memainkan game yang sama. Sambil bermain game, youtuber membagi tips dan strategi untuk menyelesaikan misi dalam game hingga berhasil. Atau dengan ditambahkan video walkthrough dan atau video cheat dari game tersebut.

Kesepuluh, video tour. Konsep video ini dikatakan cukup sederhana untuk dilakukan. kreator Atta Halilintar dan Ricis official membuat video tour di rumah atau di lokasi posisi kreator berada. Dengan video ini penonton bisa melihat kondisi sekeliling dengan lebih luas, misalnya konsep video room tour atau lokasi yang sedang kunjungi dengan menjelaskan setiap apa yang ditemukan pada video.

Pada konten Atta Halilintar pada bulan September 2019, pada usianya 24 tahun, jumlah subscriber di YouTube miliknya mencapai hampir 19 juta dengan pendapatan mencapai hampir 500 juta perbulan. Atta Halilintar adalah Influencer pertama di Asia Tenggara dengan subscribers 19,6 Juta. Dengan kata lain, jika dilihat dari penonton per video kurang lebih 1-2 juta, maka akan sangat berpengaruh pada penyampaian pesan. Media massa adalah sebuah channel atau tempat yang digunakan sebagai sarana dalam proses komunikasi massa. Atta Halilintar memilih media online (digital media) yaitu melalui program atau channel-channel seperti blog, website, maupun aplikasi-aplikasi jejaring sosial lainnya seperti youtube. Keuntungan penyebaran informasi melalui media massa adalah keunggulannya dalam penyampaian informasi yang sama kepada khalayak ramai dalam waktu relatif serentak. Banyak brand yang mengajak kerjasama dengan youtuber karena saat ini youtube lebih utama dikalangan anak muda dan kaum milenial daripada televisi. Selain murah, video promosi dikemas dengan menarik dan sesuai style dari youtuber itu sendiri. Atta juga sering menyelipkan pesan pesan positif, memberikan semangat kepada viewersnya, dan mengajak untuk tetap berbuat baik dan ingat kepada Tuhan. Keberhasilan Atta dalam promosi di youtube channel nya adalah AHHA clothingan yang dimiliki Atta sendiri sudah banyak dibeli oleh masyarakat Indonesia. Terlebih saat ada Edisi Grebek, Atta selalu memberikan Hoodie AHHA kepada bintang tamu, sehingga menambah strategi promosinya juga. Pembukaan konten "Terima kasih sudah klik video ini, Tapi jangan lupa guys klik tombol subcribe karna subcribe itu gratis, Dengan subcribe kamu support channel ini terus untuk upload hampir setiap hari. Selamat menonton enjoy". Penutup konten: pada YouTube-nya dengan narasi THANKYOU FOR WATCHING, SUBSCRIBE. Konstruksi konten terlihat pada table di bawah ini:

Tabel 1. Konten YouTube Atta Halilintar bulan Februari 2019

\begin{tabular}{|c|c|c|}
\hline No & JUDUL & \\
\hline 1 & $\begin{array}{lrr}\text { ATTA } & \text { NYAMAR } & \text { JADI } \\
\text { GEMBEL } & \text { MASUK } & \text { RESTO } \\
\text { MEWAH!! } & & \end{array}$ & $\begin{array}{l}\text { Atta menyamar menjadi gember dengan berpakaian lusuh, } \\
\text { penyamaran di mulai di menit ke empat, baru beberapa menit } \\
\text { prank gagal karena dikenali oleh pegawai restoran dan akhirnya } \\
\text { atta menyelesaikan pranknya. }\end{array}$ \\
\hline 2 & $\begin{array}{lr}\text { GEMBEL } & \text { PRANK } \\
\text { LAMBORGHINI! } & \text { ATTA } \\
\text { MEMALUKAN! } & \end{array}$ & $\begin{array}{l}\text { Atta dari Jakarta menuju Bali, sudah janjian menyewa make up } \\
\text { artis untuk mendandani seperti gembel, kemudia atta pergi ke } \\
\text { toko Oleh Oleh Ajik Krisna dan membungkus mobik } \\
\text { Lamborghini Ajik dengan pastik, Ajik krisna marah dengan } \\
\text { pegawai karena tidak mencegah dan tidak tahu siapa yang } \\
\text { membungkus, kemudian atta dengan pakaian gembel data dan } \\
\text { memberi surprise Ajik. }\end{array}$ \\
\hline 3 & $\begin{array}{l}\text { GEMBEL NAIK PESAWAT } \\
\text { BUSINESS CLASS! Urat Malu } \\
\text { Putus! }\end{array}$ & $\begin{array}{l}\text { dan make up yang } \\
\text { pihak Bandara, beb }\end{array}$ \\
\hline 4 & 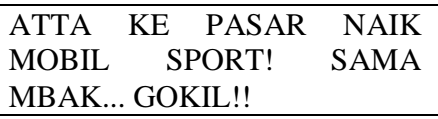 & $\begin{array}{l}\text { rena baginya ke pasar } \\
\text { r. }\end{array}$ \\
\hline 5 & $\begin{array}{lccc}\text { Detik Detik } & 10 & \text { JUTA } & \text { SUBS } \\
\text { PERTAMA } & \text { DI } & \text { ASIA } \\
\text { TENGGARA! } & & \\
\end{array}$ & $\begin{array}{l}\text { na tidak } \\
\text { meminta }\end{array}$ \\
\hline 6 & 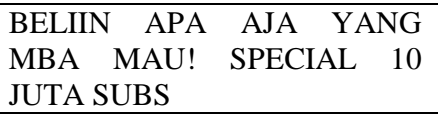 & $\begin{array}{l}\text { Setelah belanja ke pasar, Atta dan mba ART pergi ke Mall. Atta } \\
\text { mentraktir ART nya untuk belanja sepuasnya, dan setelah itu } \\
\text { diajak makan malam bersama tim juga. }\end{array}$ \\
\hline 7 & $\begin{array}{lll}\text { BONGKAR } & \text { MOBIL } & \text { RAFFI } \\
\end{array}$ & Atta bertamu ke rumah raffi ahman, dan ingin raffi mereview \\
\hline
\end{tabular}




\begin{tabular}{|c|c|c|}
\hline & $\begin{array}{l}\text { MAD. Modifikasi Miliaran } \\
\text { piah! \#AttaBongkarMobil }\end{array}$ & $\begin{array}{l}\text { obil yang baru di modifikasi dengan harga } 1 \text { Miliar. Atta } \\
\text { gum karena interiornya mewah dan keren. }\end{array}$ \\
\hline 8 & $\begin{array}{l}\text { ATTA DIPAKSA BELI MOBIL } \\
\text { RAFFI AHMAD CASH!! }\end{array}$ & $\begin{array}{l}\text { Setelah bongkar mobil raffi ahmad, raffi ahmad menantang atta } \\
\text { untuk membeli mobil mercedes benz milik raffi dengan } \\
\text { membayar cash. Sebenarnya raffi ingin menjual mobil tersebut, } \\
\text { namun memang belum bertemu pembeli yang pas.Pada saat atta } \\
\text { ditawari dengan harga yang dibisikkan maka atta deal membeli } \\
\text { mobil tersebut. }\end{array}$ \\
\hline 9 & $\begin{array}{l}\text { ATTA PRANK LUCINTA } \\
\text { LUNA SAMPAI NANGIS !! }\end{array}$ & $\begin{array}{l}\text { Atta membuat rencana prank Lucinta Luna. } \\
\text { Ale, secutiry di rumah atta memarahi Lucinta karena berisik } \\
\text { klakson di depan rumah, tidak memperbolehkan Lucinta masuk } \\
\text { tanpa dapat izin dari Atta melalui telepon. hingga Lucinta nangis } \\
\text { dan melempar handphone nya. Kemudian Atta dan tim keluar } \\
\text { dan menyebutkan bahwa kejadian tersebut adalah prank. }\end{array}$ \\
\hline 10 & 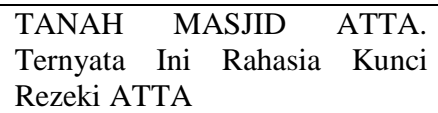 & $\begin{array}{l}\text { Sesuai nazar Atta sebelumnya bahwa jika subscribernya tembus } \\
\text { 10juta maka akan membangun masjid. Di video ini Atta sedang } \\
\text { mencari tanah di daerah Bogor yang akan dibangun masjid. }\end{array}$ \\
\hline 11 & $\begin{array}{l}\text { BONGKAR MOBIL LUCINTA } \\
\text { LUNA! \#AttaBongkarMobil }\end{array}$ & $\begin{array}{l}\text { Setelah melakukan prank dan berhasil dengan Lucinta Luna, Atta } \\
\text { ingin review mobil mewah Lucinta. Disana berisi barang-barang } \\
\text { yang biasa dibawa pada saat syuting ataupun pergi sehari-hari, } \\
\text { tidak sengaja Atta menemukan sesuatu yang tidak sewajarnya } \\
\text { dimiliki wanita. }\end{array}$ \\
\hline 12 & $\begin{array}{l}\text { PACAR BARU LUCINTA } \\
\text { LUNA! FATIH?? } \\
\text { \#AttaBongkarMobil }\end{array}$ & $\begin{array}{l}\text { Video ini adalah lanjutan dari video tanggal } 12 \text { Februari } 2019 . \\
\text { Masih seputar bongkar mobil Lucinta Luna. Mereka membahas } \\
\text { pacar Lucinta yang sudah } 6 \text { bulan berpacaran. }\end{array}$ \\
\hline 13 & ANGAN BARU ATTA & $\begin{array}{l}\text { litu kucing. Anggota baru } \\
\text { Cat dengan ID Instagram }\end{array}$ \\
\hline 14 & $\begin{array}{l}\text { MOGE BARU } \\
\text { ANGAN \#Sunmori }\end{array}$ & $\begin{array}{l}\text { ling Moge di Jakarta. } \\
\text { al. }\end{array}$ \\
\hline 15 & $\begin{array}{l}\text { ATTA Mng di PUBG Indonesia } \\
-\quad \text { MEET N GREET MATI } \\
\text { TERUS KOCAK!! }\end{array}$ & $\begin{array}{l}\text { an mengajak viewers nya untuk bergabung di } \\
\text { a. }\end{array}$ \\
\hline 16 & $\begin{array}{l}\text { NYAMAR JADI SULTAN! } \\
\text { Traktir Tukang Parkir, Ojek, } \\
\text { Pengemis. Naik Mobil Emas }\end{array}$ & $\begin{array}{l}\text { Atta mengajak Penjual Jajan, Tukang Ojek, dan Tukang Parkir } \\
\text { untuk naik ke mobilnya, kemudian mereka diminta untuk belanja } \\
\text { selama } 1 \text { menit di aplikasi shopee dan akan dibayar oleh Atta } \\
\text { (Video sponsor). }\end{array}$ \\
\hline 17 & $\begin{array}{l}\text { Detik Detik } 11 \text { JUTA Subs } \\
\text { Pertama Di Asia Tenggara + } \\
\text { Room Tour Studio Baru... } \\
\end{array}$ & $\begin{array}{l}\text { ta menuju } 11 \text { juta subcriber. Atta berterima kasih kepada } \\
\text { bcriber nya dan memotivasi untuk terus berkarya. }\end{array}$ \\
\hline 18 & $\begin{array}{lrr}\text { ATTA DIAMOND } & \text { PLAY } \\
\text { BUTTON Pertama } & \text { Di } & \text { ASIA } \\
\text { TENGGARA! } 11 \text { M SUBS! + } & \text { SUBRE } \\
\text { GREBEK } & \text { KANTOR } \\
\text { YOUTUBE } & & \\
\end{array}$ & $\begin{array}{l}\text { Pada saat penyerahan Diamond play buttonj Atta mendapat } \\
\text { surprise dari Youtube dan keluarga dengan video ucapan yang } \\
\text { sudah dipersiapkan keluarganya. }\end{array}$ \\
\hline 19 & $\begin{array}{l}\text { UNBOXING BERLIAN DARI } \\
\text { YOUTUBE! DIAMOND PLAY } \\
\text { BUTTON PERTAMA DI ASIA } \\
\text { TENGGARA! }\end{array}$ & $\begin{array}{l}\text { Atta membuka Diamond play button dan memberi tahu bahwa } \\
\text { koper pembungkus nya sangat kokoh dan diamond yang didalam } \\
\text { asli swaroski. }\end{array}$ \\
\hline 20 & $\begin{array}{lr}\text { BEK RUMAH } & \text { MEWAH! } \\
\text { J NYA Supir } & \text { ANGKOT } \\
\text { IRANG } & \text { PUNYA } \\
\text { L+HOTEL } & \\
\text { nan \#AttaGrebekRumah } \\
\end{array}$ & $\begin{array}{l}\text { Atta mengunjungi rumah Babe Basko, seorang yang kaya raya, } \\
\text { dulu nya Babe Basko tidak taman SD, sempat menjadi supir } \\
\text { angkot. Video ini dibuat bertujuan untuk memberikan inspirasi } \\
\text { kepada generasi milenial. }\end{array}$ \\
\hline 21 & $\begin{array}{l}\text { GREBEK GARASI MEWAH } \\
\text { SUPIR ANGKOT! RAHASIA } \\
\text { SUKSES JADI MILIARDER! } \\
\text { Dari Gaji } 300 \text { rupiah jadi } \\
\text { Miliarder }\end{array}$ & $\begin{array}{l}\text { Atta datang kerumah Mewah yaitu Babeh Basko. Atta kenal } \\
\text { melalui komunitas mobil Harley Davidson. Dalam video ini } \\
\text { berisi mengenai review rumah Babeh Basko. }\end{array}$ \\
\hline 22 & $\begin{array}{lll}\text { GREBEK LIMBAD HORORR.. } \\
\text { Isinya Bikin } & \text { Merindingg } \\
\text { \#AttaBongkarMobil }\end{array}$ & $\begin{array}{l}\text { ta Grebek mobil Limbad, Dari awal video, membuka bagian } \\
\text { gasi, berisi benda benda mistis. }\end{array}$ \\
\hline 23 & $\begin{array}{l}\text { DI PRANK LIMBAD CINCIN } \\
\text { MAHAL ATTA DI KUNYAH! }\end{array}$ & $\begin{array}{l}\text { Atta melihat limbad makan paku dengan santai, atta panik dan } \\
\text { takut karena paku yang dimakan banyak. Atta bingung mengapa } \\
\text { limbad suka dan mau makan paku. }\end{array}$ \\
\hline
\end{tabular}


Website : http://sosial.unmermadiun.ac.id/index.php/sosial

\begin{tabular}{|l|l|l|}
\hline 24 & \multicolumn{1}{|c|}{$\begin{array}{l}\text { Selama ini Atta tahu bahwa limbad tidak mau berbicara di depan } \\
\text { kamera, namun ketika istirahat syuting atta memergoki Limbad } \\
\text { berbicara dengan kru nya, dan kemudian video dilanjutkan } \\
\text { dengan tanya jawab dengan bantuan asisten limbad untuk } \\
\text { menyampaikan kepada atta }\end{array}$} \\
\hline 25 & $\begin{array}{l}\text { Bongkar Motor 7 Milyar Marc } \\
\text { Marquez \& Motor Juara Asia } \\
\text { AHRT! }\end{array}$ & $\begin{array}{l}\text { Atta melakukan wawancara kepada atlit balap motor kebanggaan } \\
\text { Indonesia, kemudian atta menaiki panggung untuk menunjukan } \\
\text { motor honda RC213V-S Motor Marc Marquez versi jalan raya }\end{array}$ \\
\hline
\end{tabular}

Tabel 1. Konten YouTube Ria Ricis bulan Februari 2019

\begin{tabular}{|c|c|c|}
\hline No & JUDUL & ISI KONTEN \\
\hline 1 & $\begin{array}{l}\text { LIAT ISI RUNAH DEMIAN, } \\
\text { RAHASIA MAGIC - RICIS } \\
\text { KEPO }\end{array}$ & $\begin{array}{l}\text { Video ini merupakan salah satu episode dari \#RicisKepo. Di } \\
\text { video ini Ria ricis atau biasa dipanggil Ricis bertamu ke } \\
\text { kediaman DEMIAN ADITYA, seorang pesulap terkenal di } \\
\text { Indonesia. Demian mengajak ricis untuk melihat beberapa } \\
\text { ruangan di rumahnya, seperti ruang tamu, ruang musik, dan } \\
\text { ruang kerja miliknya. Demian menjelaskan bahwa rumahnya } \\
\text { mengambil tema classic, dalam artian ruang tamu dan ruang } \\
\text { keluarga itu terpisah. Ruang tamu biasanya digunakan untuk } \\
\text { tempat nongkrong teman teman mbak SARA (istri demian). Di } \\
\text { dalam ruang musik terdapat beberapa alat musik seperti piano } \\
\text { dan gitar, alat musik tersebut adalah milik istrinya. Dan terakhir } \\
\text { di dalam ruang kerja demian lebih dominan kaca di dinding } \\
\text { dinding nya, kaca tersebut digunakan untuk papan tulis saat } \\
\text { meeting, jadwal, atau sebagai tempat catatan. Terdapat peralatan } \\
\text { untuk keperluan membuat konten channel youtube miliknya } \\
\text { seperti; kamera dan lighting serta terdapat suatu lemari } \\
\text { penyimpanan yang digunakan untuk menyimpan keperluan } \\
\text { magic nya. Demian juga menceritakan beberapa penghargaan } \\
\text { penghargaan yang ia dapatkan. Di sela sela pembicaraan demian } \\
\text { menceritakan kedatangan ria ricis yang terlambat karena baru } \\
\text { bangun tidur } \square \text {. }\end{array}$ \\
\hline 2 & $\begin{array}{l}\text { ARSY DAN AUREL } \\
\text { BERHIJAB CANTIK } \\
\text { BANGET } \square \text { - RICIS KEPO }\end{array}$ & $\begin{array}{l}\text { Video ini merupakan salah satu episode dari \#RicisKepo. Di } \\
\text { video ini, Aurel dan arsy sedang belajar menggunakan hijab } \\
\text { dengan ria ricis. Ria ricis juga menanyakan beberapa pertanyaan } \\
\text { tentang perjalanan cinta aurel seperti, apa penyebab dia putus dan } \\
\text { bagaimana kriteria pasangan hidupnya. }\end{array}$ \\
\hline 3 & $\begin{array}{l}10 \text { JUTA SUBSCRIBER DI } \\
\text { AJAK KEBUT-KEBUTAN!!! } \\
\text { GA SANGGUUUUPPP w/Imam } \\
\text { Darto -RICIS KEPO }\end{array}$ & $\begin{array}{l}\text { Video ini merupakan salah satu episode dari \#RicisKepo. Di } \\
\text { video ini Ria ricis atau biasa dipanggil Ricis bertamu ke } \\
\text { kediaman Imam Darto atau biasa dipanggil om Darto. Pada } \\
\text { kedatangannya itu Ria Ricis meriview beberapa kendaaran milik } \\
\text { om Darto seperti moge dan mobil jeep. Om darto menceritakan } \\
\text { kisah kisah kendaraan tersebut dari mulai cara mendapatkanya, } \\
\text { asal kendaraannya, sampai harga kendaraan tersebut. Ria ricis } \\
\text { juga mendapat kesempatan mencoba mobil jeep mini milik om } \\
\text { Darto. }\end{array}$ \\
\hline 4 & $\begin{array}{l}\text { ROMBAK KAMAR JADI } \\
\text { ISTANA MAINAN }\end{array}$ & $\begin{array}{l}\text { Di video ini Ria ricis mereview atau unboxing mainan mainan } \\
\text { yang ia beli untuk keponakannya, seperti mainan dari disney, } \\
\text { mainan dapur dapuran, kolam renang plastik. Di sela sela video } \\
\text { ricis mengingatkan para penonoton untuk mengikutj lomba dance } \\
\text { di salah satu aplikasi. }\end{array}$ \\
\hline 5 & $\begin{array}{l}\text { DEMI \#TheRicis SAYA } \\
\text { HARUS KUAT. }\end{array}$ & $\begin{array}{l}\text { Di video ini Ria ricis menjenguk salah satu fans nya di salah satu } \\
\text { rumah sakit. Tapi ternyata setelah menjenguk fansnya, kesehatan } \\
\text { ria ricis tiba tiba nge drop dan harus rawat inap. }\end{array}$ \\
\hline 6 & $\begin{array}{l}\text { TIM RICIS BELANJA } \\
\text { SEPUASNYA } \square \text { AKHIRNYA!!! } \\
\text { Demi Gak Pindah Ke Rans }\end{array}$ & $\begin{array}{l}\text { Ria ricis beserta tim nya pergi ke sustu pusat perbelanjaan. } \\
\text { Disana tim ricis berbelanja sepuasnya dan dibayar oleh ricis. } \\
\text { Mereka juga me nake over salah satu tim ricis yaitu BOIM. }\end{array}$ \\
\hline 7 & $\begin{array}{l}\text { MERMAID KEJEPIT DI BAN } \\
\text { BERENANG }\end{array}$ & $\begin{array}{l}\text { Video ini merupakan part } 2 \text { dari video sebelumnya. Di video ini } \\
\text { ria ricis dan temannya menjelaskan beberapa mainan barunya } \\
\text { seperti trampolin, bban berenang dan lain lain. }\end{array}$ \\
\hline 8 & $\begin{array}{l}\text { BANGUN PAGI MASIH DI } \\
\text { RUANG RAWAT INAP... }\end{array}$ & $\begin{array}{l}\text { Video ini adallah video vlog morning routine ria ricis selama ia } \\
\text { di rawat inap di slaah satu rumah sakit. }\end{array}$ \\
\hline 9 & $\begin{array}{l}\text { PERTAMA KALI NGEVLOG } \\
\text { SAMA MBA SUM, WAH }\end{array}$ & $\begin{array}{l}\text { Di video ini ria ricis berencana mengePRANK permbantu nya. } \\
\text { Mula mula Dia bersenda gurau dengan pembantu nya saat ia }\end{array}$ \\
\hline
\end{tabular}


Website : http://sosial.unmermadiun.ac.id/index.php/sosial

\begin{tabular}{|c|c|c|}
\hline & $\begin{array}{l}\text { CALON VLOGGER NIH (part } \\
\text { 1) }\end{array}$ & sedang memasak \\
\hline 10 & $\begin{array}{l}\text { PRANK MBA SUM BIKIN } \\
\text { MAKANAN SAMPE ADA } \\
\text { YANG PINGSAN!! Kasian sih } \\
\text { tapi ngakak (part 2) }\end{array}$ & $\begin{array}{l}\text { Di video ini ria ricis beserta timnya mengePRANK mba sum, } \\
\text { pembantu di rumahnya. Prank tersebut berhasil dan membuat } \\
\text { mbak sum bingung dan khawatir }\end{array}$ \\
\hline 11 & $\begin{array}{l}\text { Untuk Alm. Kak Olga. Ziarah } \\
\text { Ke Makam Kak Olga }\end{array}$ & $\begin{array}{l}\text { Ricis, timnya, dan bang billy. Pergi ziarah ke makam alm. Olga. } \\
\text { Mereka datang untuk mendoakan alm. Olga. }\end{array}$ \\
\hline 12 & $\begin{array}{l}\text { Dapet Banyak Boneka Dari } \\
\text { Mesin Capit Timezone! Tim } \\
\text { ricis } \times \text { keluarga cemara }\end{array}$ & $\begin{array}{l}\text { Ricis, timnya dan keluarga cemara pergi ke suatu mall, diana } \\
\text { mereka bermain di tempat permainan. Ricis memainkan game } \\
\text { capit boneka dan mendapatkan boneka yang sangat banyak }\end{array}$ \\
\hline 13 & $\begin{array}{l}\text { Seharian Sama Bang Sandi. } \\
\text { Aslinya Ganteng Banget } \square . \text { - } \\
\text { Eksklusif }\end{array}$ & $\begin{array}{l}\text { Ria ricis di undang di acar launching merchendise sandi uno. Ria } \\
\text { ricis menggunakan kesempatan tersebut dengan mengajak kan } \\
\text { sandi uno QnA atau di tanyai oleh ria ricis berbagai pertanyaan } \\
\text { dari netizen. }\end{array}$ \\
\hline 14 & $\begin{array}{l}\text { TIM RICIS BELANJA } \\
\text { SEPUASNYA JUTAAN } \\
\text { RUPIAH SAMPE MALL } \\
\text { TUTUP!!!(PART 2) }\end{array}$ & Video ini merupakan part 2 atau lanjutan dari video sebelumnya. \\
\hline 15 & $\begin{array}{l}\text { PIZZA UNTUK MBA SUM, } \\
\text { KAMI SAYANG MBA } \\
\text { SUM!!!!! }\end{array}$ & $\begin{array}{l}\text { Ria ricis membelikan ART nya sebuah pizza yang dimakan } \\
\text { bersama dengan ricis sebagai permintaan maaf karena kemarin } \\
\text { sudah di prank hingga kebingungan. }\end{array}$ \\
\hline 16 & $\begin{array}{l}\text { DETIK-DETIK } 10 \text { JUTA } \\
\text { SUBSCRIBER PEREMPUAN } \\
\text { SATU-SATUNYA. GA BISA } \\
\text { BERHENTI NANGIS... }\end{array}$ & $\begin{array}{l}\text { Video ini meripakan detik detik dimana chanel RICIS } \\
\text { OFFICIAL mendapat } 10 \text { juta subscriber dan ria ricis sebagai satu } \\
\text { satu nya youtuber perempuan yang mencapai } 10 \text { juta subscriber. } \\
\text { Menurut ria ricis ini merupakan hasil kerja keras semua orang } \\
\text { dia, timnya, dan hasil suport the ricis. }\end{array}$ \\
\hline 17 & $\begin{array}{l}\text { AKHIRNYA KETEMU } \\
\text { FATHER OF YOUTUBE, } \\
\text { Dikritik Abis-Abisan } \square \text {-RICIS } \\
\text { KEPO }\end{array}$ & $\begin{array}{l}\text { Ria ricis memberikan beberapa pertanyaan kepada deddy } \\
\text { corbuzier. Disini deddy juga menyelipkan kritikan dan motivasi }\end{array}$ \\
\hline 18 & $\begin{array}{l}\text { RICIS KETEMU HANTU DI } \\
\text { GEDUNG TUA w/SARA } \\
\text { WIJAYANTO }\end{array}$ & $\begin{array}{l}\text { Ria Ricis bersama Sara wijayanto: istri magecian demian Aditya } \\
\text { yang indigo mndatangi sebuah bangunan tua yang tidak } \\
\text { berpenghuni. }\end{array}$ \\
\hline 19 & $\begin{array}{l}\text { NAGITA SLAVINA PAKAI } \\
\text { HIJAB, Cantik Banget } \square \text { Sambil } \\
\text { Curhat -RICIS KEPO }\end{array}$ & $\begin{array}{l}\text { Di video ini nagita slavina mengenakan hijab. Ria riciis dan } \\
\text { nagita adalah best friend forever. } \\
\text { Ria ricis juga mengajukan beberapa pertnyaan untuk nagita. }\end{array}$ \\
\hline 20 & $\begin{array}{l}\text { Prank Channel Youtube Ricis } \\
\text { Dibanned! Bye Gak Ngeyoutube } \\
\text { Lagi } \square\end{array}$ & $\begin{array}{l}\text { Salah satu tim ricis mengrprank Ria Ricis drngan mengatakan } \\
\text { bahwa channel youtube nya tidak bisa di akses secara permanent. } \\
\text { Orank tersebut berhasil hingga membiat ria rucis menangis } \\
\text { kebingungan. }\end{array}$ \\
\hline 21 & $\begin{array}{l}\text { Ricis Dikerjain Abis-Abisan } \\
\text { Sama Rafatar } \square \text { Usil Banget!! }\end{array}$ & $\begin{array}{l}\text { Ricis bertamu di runah naguta dan bermain dengan rafatar. Ricis } \\
\text { di suruh-suruh oleh rafatar. }\end{array}$ \\
\hline 22 & $\begin{array}{l}\text { DETIK-DETIK } \\
\text { PENYERAHAN DIAMOND } \\
\text { PERTAMA DI ASIA } \\
\text { TENGGARA }\end{array}$ & $\begin{array}{l}\text { Ini merepukan vlog tim ricis disaat penyerahhan diamond play } \\
\text { button. }\end{array}$ \\
\hline 23 & $\begin{array}{l}\text { Akhirnya Room Tour Kamar } \\
\text { Tidur Serba Pink \& Hello } \\
\text { Kitty } \square\end{array}$ & $\begin{array}{l}\text { Ricis menunjukkan bebarapa ruangan yang ada di rumah barunya } \\
\text { terutama kamar tidurnya. Kamar tidur ria ricis lebih dominan } \\
\text { warna pink dan memiliki ornamen ornamen hello kitty }\end{array}$ \\
\hline 24 & $\begin{array}{l}\text { Liat Isi Rumah Ayu Dewi, Ada } \\
\text { Lol Suprise Jumbo } \square \text {-RICIS } \\
\text { KEPO (part 1) }\end{array}$ & $\begin{array}{l}\text { Ayu dewi menunjukkan bebarapa ruangan yang ada di rumah nya } \\
\text { dan tema rumahnya adalah glitter. }\end{array}$ \\
\hline 25 & $\begin{array}{l}\text { UNBOXING DIAMOND } \\
\text { BUTTON DI AIR TERJUN } \\
\text { BARENG KELUARGA } \\
\text { MERMAID. EKSKLUSIF!!! }\end{array}$ & $\begin{array}{l}\text { Ria ricis membuka kotak diamond play button nya yang ia } \\
\text { dapatkan. Ia mengatakan bahwa play button itu terbuat dari } \\
\text { berlian asli. }\end{array}$ \\
\hline 26 & $\begin{array}{l}\text { Orang Kaya! Rumah Ayu Dewei } \\
\text { Banyak Banget -Ricis Kepo } \\
\text { (part 2) }\end{array}$ & $\begin{array}{l}\text { Viideo ini merupakan lanjutan dari video sebelumnya. Ayu dewi } \\
\text { menunjukkan beberapa ruangan di rumah nya yang lain. }\end{array}$ \\
\hline 27 & $\begin{array}{l}\text { MAIN ICE SKATING FULL } \\
\text { TEAM. RUSUH BANGET } \\
\text { AMPUUUNNNN... }\end{array}$ & $\begin{array}{l}\text { Ria ricis bersama timnya bermain ice skating di salah satu mall. } \\
\text { Di dini tim ricis menggunakan baju bari yang dibeli di video } \\
\text { sebelumnya. }\end{array}$ \\
\hline 28 & $\begin{array}{l}\text { TIPS PUTIH CUMA DENGAN } \\
\text { MASKERAN PAKE BERAS. }\end{array}$ & $\begin{array}{l}\text { Ria ricis memberikan saran saran kepada penonton tentang } \\
\text { masker wajah alami yang dapat memutihkan kulit wajah. Disini }\end{array}$ \\
\hline
\end{tabular}


Website : http://sosial.unmermadiun.ac.id/index.php/sosial

\begin{tabular}{|c|l|l|}
\hline & $\begin{array}{l}\text { YANG MAU PUTIH WAJIB } \\
\text { NONTON. }\end{array}$ & ria ricis ditemani vazo ahmad salah satu tim dan temannya. \\
\hline 29 & $\begin{array}{l}\text { Akhirnya Ketemu The Sungkar! } \\
\text { Rusuh Banget PART 1 }\end{array}$ & $\begin{array}{l}\text { Disini the sungkar family mempraktekkan gaya gaya hijab ala } \\
\text { mereka sambil menjawab pertanyaan yang diajukan followers ria } \\
\text { ricis. }\end{array}$ \\
\hline 30 & $\begin{array}{l}\text { KEPO ISI RUMAH THE } \\
\text { SUBGKAR, SAMPAI DIUSIR } \\
\text { SATPAM... -Ricis Kepo(part 2) }\end{array}$ & $\begin{array}{l}\text { The sungkar memperlihatkan beberapa tempat di apartemen } \\
\text { mereka seperti taman dan perpustakaan. }\end{array}$ \\
\hline
\end{tabular}

Sumber: data penelitian

Berdasarkan beberapa konten tersebut nampak bahwa konsep konten YouTube untuk menarik viewer dan meningkatkan subcriber. YouTube berfungsi sudah lebih dari TV kalau ditinjau dari jumlah penontonnya. YouTube menjadi pilihan untuk mendapatkan penghasilan yang tinggi. Konsep Vlog, Foodie, Do It Yourself (DIY) dan Hacks, Beauty, Gaming, Short Movie, Prank, cover lagu, politik, olahraga, review gadget, parodi dikemas untuk tujuan monetisasi. Konten-konten channel secara elemen visual dan audio secara diarahkan memiliki nilai komersial, Meskipun tidak dipungkiri dibutuhkan proses, kreatifitas, konsistensi menciptakan konten, dan kerja keras dalam membuat konten yang kreatif. Passion, skill, dan pengetahuan YouTuber dibutuhkan sebagai daya tarik subscriber dan follower. Konten YouTube terlihat memiliki shareability, penonton diajak conversation, terdapat interactivity dengan pengunjung, terdapat konsistensi, memiliki sasaran penggemar tersendiri, suistainable juga dijaga, konten mudah ditemukan (discoverability), mudah diakses (accessibility), beberapa dilakukan dengan kolaborasi, dan menjadi inspirasi bagi viewer.

\section{PENUTUP}

Keberadaan YouTube sejak tahun 2005, saat ini menjadi jejaring sosial ke dua yang paling popular di dunia setelah facebook. Dengan pengguna 1,9 milyar, media sosial berbasis video YouTube ini digunakan untuk saling berbagi konten dan komentar. Pengguna YouTube di Indonesia sudah mencapai 50 juta orang. YouTube menjadi platform sosial yang paling aktif digunakan di Indonesia saat ini. Youtube digunakan sebagai media promosi berbasis PPC (Pay Per Click) dimana setiap video yang dianggap memenuhi syarat di dalamnya terdapat iklan Google Adsense. Youtube menjadi ladang uang bagi banyak YouTuber di Indonesia. Konstrusi konten YouTube Atta Halilintar dan Ricis official sebagai penerima penghargaan Diamond Play Button dengan memilih konsep untuk mendapat like, coment dan subcribers. Strategi kreatif yang digunakan YouTuber pada konten videonya lebih cenderumg kuat pada faktor komersial dan ekonomi. Perkembangan konsep konten YouTube yang tidak hanya sebagai wadah ekspresi diri namun juga menjadi media pemasaran korporasi mempertegas bahwa telah terjadi proses komodifikasi pada proses kreatif kreator yang memanfaatkan kreatifitas, ruang ekspresi diri, dan interaksi antara penonton dan kreator. YouTube merupakan pasar yang besar, YouTube menjadi peluang untuk menarik audiens yang besar dan luas. Penarikan audiens dilakukan melalui konten-konten yang diunggah di media sosial. Hal ini pun menarik banyak perusahaan maupun lembaga menjadi sponsor sekaligus terjun membuat konten di media sosial demi mencapai tujuan mereka dan kebutuhan audiens.

\section{VI.DAFTAR PUSTAKA}

Adorno, Theodor W. 1991. The Culture Industry: Selected essays on mass culture. Routledge: London

Baudrillard, Jean. 1981. Simulacra and Simulation (Sheila Faria Glaser, Penerjemah). Michigan: The University of Michigan Press, 1994

Bolaño, César R. S., Eloy S. Vieira. 2015. "The Political Economy of the Internet: Social Networking Sites and a Reply to Fuchs. "Television \& New Media Vol. 16, No. 1, hal. 52-61. London: Sage Publications. Diakses pada 15 Juli 2019 pukul 14.04 WIB melalui: http://remotelib.ui.ac.id:3671/content/16/1/52.full.pdf+html

Fuchs, Christian. 2016. Critical Theory of Communication: New Readings of Lukács, Adorno, Marcuse, Honneth and Habermas in the Age of the Internet.London: University of Westminister Press. Diakses pada 15 Juli 2019 pukul $13.21 \quad$ WIB melalui: http://www.uwestminsterpress.co.uk/site/books/detail/1/critical-theory-of-communication

Infopedia. 2019. 10 Jejaring Sosial Paling Populer di Dunia 2019. YouTube: Dipublikasi tanggal 15 Februari 2019

Inpemedia Tv. 2019. 5 Media Sosial dengan pengguna terbanyak. YouTube: Dipublikasi tanggal 1 April 2019

Kangal, Kaan. 2016. “The Karl Marx Problem in Contemporary New Media Economy: A Critique of Christian Fuchs' Account.” Television \& New Media, Vol. 17, No. 5, hal. 416-428. Diakses pada 15 Juli 2019 pukul 14.07 WIB melalui: http://remote-lib.ui.ac.id:3671/content/17/5/416.full.pdf+html

Lewis, Jane et al. 2014. Qualitative Research Practice: A Guide for Social Science Students and Researchers.London: Sage Publications

Lupton, Deborah. 2015. Digital Sociology. Oxon: Routledge

Marvasti, Amit B. 2004. Qualitative Research in Sociology: An Introduction.London: Sage Publications

Naisbitt, John, and Aburdence, Patricia. (1990). Megatrends 2000. London: Sidwick and Jackson.

Neuman, W. Laurence. 2006. Social Research Methods: Qualitative and Quantitative Approaches, Sixth Edition.Boston: Pearson

Snickars, Pelle and Patrick Vonderau. 2010. The YouTube Reader. Sweden: National Library of Sweden.

https://journal.ugm.ac.id/jps/article/view/28584/pdf 